\title{
焼結鋼におけるCuの代替としてのBおよびCの添加
}

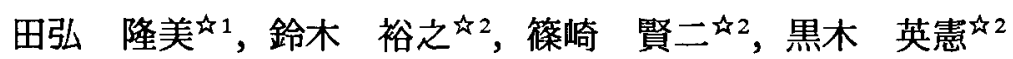 \\ 41 広島大学大学院, 干739-8527 東広島市鏡山 1-4-1 (現: 三菱重工㑍). \\ 42 広島大学機械システム工学専攻, テ 739-8527 東広島市鏡山 1-4-1.
}

\section{Addition of Boron and Carbon Instead of Copper in P/M Steel}

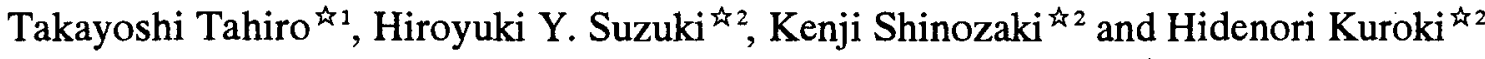 \\ ${ }^{4}$ ' $G$ raduate School, Hiroshima University (Present Address: Mitsubishi Heavy Industries).

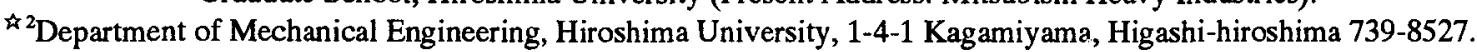

Received March 23, 2001

\section{SYNOPSIS}

Copper is one of the most important alloying elements in sintered steel parts. However, reduction or removal of copper in the parts which are mainly used in automobiles is desirable for the promotion of recycling of steel from scrapped cars.

Calculation with a thermodynamic software and observation of slumping in shape of small compacts have indicated a low melting point near $1400 \mathrm{~K}\left(1127^{\circ} \mathrm{C}\right)$ in the (lmass $\% \mathrm{Cr}-0.7$ mass $\% \mathrm{Mn}-0.3$ mass $\left.\% \mathrm{Mo}\right)$ steel-2.5mass $\% \mathrm{~B}-1$ mass $\% \mathrm{C}$ powder mixture. The temperature is comparable to the melting point of copper or $1357 \mathrm{~K}\left(1084^{\circ} \mathrm{C}\right)$. Thus, boron with carbon is a candidate replacement for copper at temperatures no higher than $1423 \mathrm{~K}\left(1150^{\circ} \mathrm{C}\right)$ which can be easily reached in a conventional mesh belt furnace.

The addition of 2 mass $\%$ of the low-melting-point mixture or the combined addition of 0.05 mass $\% \mathrm{~B}$ and $1 \mathrm{mass} \% \mathrm{C}$ to the $\mathrm{Cr}-\mathrm{Mn}$-Mo steel has been proved to be effective in activating sintering. The addition has provided a reduction of sharp corners in the periphery of small pores, leading to a dimple fracture and an improvement in tensile strength of a basic Cr-Mn-Mo-1mass\% $\mathrm{C}$ sintered steel by $15 \%$.

KEYWORDS

powder metallurgy, sintered steel, boron, liquid phase sintering, tensile strength

\section{1 緒 言}

自動車に多く用いられる焼結鋼へのCu添加の主な利点は， マトリックスの固溶強化, 液相による焼結促進, 銅䏽張によ る寸法調節である．他方，問題点は，Cu を含む材料がスク ラップとして製鋼原料に入った場合, Cuが鋼中に残留して加 工時に赤熱脆性の原因となり，ひいては廃自動車から出る鉄 鋼スクラップのリサイクルの妨げとなることである ${ }^{1)}$.そこ で, $\mathrm{Cu}$ の代わりに製鋼工程で容易に除去できる元素を添加す ることを考え，そのような元素の中で BとCに着目した.こ の2つの元素は, $\mathrm{Cu}$ の融点(1357K) から遠くない1450K以下 で共晶液相を生じる2)という条件を付けたとき，難点が少な い. 他の元素では， Beは人の健康に著しく有害であり，Pを 含む鋼材は勒性が劣り，また S は製鋼工程で除去すれば覀硫 酸ガスが発生し，残留させれば赤熱脆性を起こす。

B とCは共に Fe と低融点の共晶液相を生じて焼結を促進す
るほか, CはFeに固溶してマトリックスを強化し，しかもそ の固溶中に銅膨張に似た膨張を材料に引き起こして焼結収縮 を打ち消す,つまり寸法変化を抑制する効果がある.一方, B は通常, CrやMoの1/100〜1/1000の微量の添加で鋼の焼入れ 性を著しく向上させることが知られている. その点で Bの添 加は経済的でもある。

以上の検討に基づき，本研究では $\mathrm{B} と \mathrm{Cを}$ 添加元素に選び， 寸法変化の抑制とマトリックスの強化，焼結の促進を同時に 目指した. 主原料粉には， $\mathrm{Cu}$ の排除による固溶強化の消失を 補うため, 純 $\mathrm{Fe}$ 粉でなく, 溶製の機械構造用鋼で一般的な $\mathrm{Cr}$ およびMoを含む低合金の水アトマイス Cr-Mo-Mn 鋼粉を採 用した.この粉末に BとCを添加し，焼結温度は, $\mathrm{Cu}$ 添加の 代案とする立場から，Cu含有鋼の焼結に工業的に使用されて いる多くの炉の上限温度に近い $1420 \mathrm{~K}$ としいる。 


\section{2 原材料・実験方法および実験}

\section{1 原料粉}

主原料粉として水噴霧 $\mathrm{Cr}-\mathrm{Mo}-\mathrm{Mn}$ 鋼粉 (川崎製鉄侏製 KIP4100V)を採用した。その成分と粒度分布をTable 1に示す。

添加成分として使用するBの形については, 元素粉やフェロ ポロンと予合金成分の他に，ほう化鉄尚や炭化ほう素4)，窒化 ほう素》を添加した例があり，さらにほう酸系フラックスを SUS316Lステンレス鋼粉に添加し，フラックスが粉末粒子表面 の酸化膜を溶解除去する効果や，B含有共晶液相を生じて焼結 を促進する効果を利用した報告のもある。その中で，成分変更 の面倒な予合金の使用をまず除外した．また，上述の各 B 源 のうち，フラックスを使用すると圧粉密度が下がり，フェロ ボロンやほう化鉄，炭化ほう素を使用すると硬質で体積が大 きく金型摩耗を促進するので，いずれも不適当である．窒化 ほう素は潤滑性を持つ点で好ましいが，焼結中のFeへの溶解 について別に検討を要するので,これも今回は除いた. 結局, 元素粉が硬質ではあるが体積は小さくて済むので適当と考え られ，微粒で均一混合に有利な H. C. Starck社製の非晶質 B 粉 (純度 $96 \mathrm{mass} \%$, 平均粒径 $0.8 \mu \mathrm{m}, \mathrm{Knoop}$ 硬さ約 $2500 \mathrm{~kg} / \mathrm{mm}^{2}$ ) を採用することとした．Cは黒鉛とし，日本黒鉛工業侏製の 天然黒鉛粉 (純度 $99.34 \mathrm{mass} \%$ ，平均粒径 $10 \mu \mathrm{m}$ ) を採用した。 2.2 低融点合金組成の決定

$\mathrm{Fe}$ に B と C 2 元素を加えた三元系では，三元共晶点を持 つ平衡状態図か幾つか報告されている 三元共晶点のデータを見ると，ほほ Fe-(2.7 3.8mass\%B)-(0.5 １.5mass\%C)の範囲に散らばった組成と，1370１432 K の範 囲の温度が示されており，中には 1 つの二元共晶線上の $\mathrm{Fe}$ 1.7mass\%B-2.3mass\%Cに最低融点が現れるとするものもあるす など，定説は見当たらない．ただ，本研究を進める上では正 確な三元共晶点などの決定が直接必要ではなく，むしろ圧粉 体の形状を保ちつつ焼結を促進できる適量の液相生成の条件 を見出すことこそ重要である、そこで本研究では手がかりと して，共晶点を含めて低融点になる合金組成範囲を熱力学計 算ソフト(Thermo-Calc)によって求め, 次にその組成について 実験的に適否の確認を行った。

なお，計算の際の各元素の添加量は，上記の三元共晶点や 最低融点の組成を含めるために，Bについては余裕を持たせ て 0 4.5 mass\%の範囲で 0.5 mass\%刻みとした. Cは，通常の 鉄系焟結材料の場合, $1 \mathrm{mass} \%$ 程度添加される黒鉛か $\mathrm{Fe}$ 粒子 間隙に存在し, 害際のFe粒子の表面では局部的に高莀度にな

Table 1 Characteristics of Cr-Mo-Mn steel powder (KIP4100V).

\begin{tabular}{c|c|c|c|c|c|c|c}
\hline \multicolumn{7}{c}{ Chemical composition (mass\%) } \\
\hline T.C & $\mathrm{Si}$ & $\mathrm{Mn}$ & $\mathrm{P}$ & $\mathrm{S}$ & $\mathrm{Cr}$ & $\mathrm{Mo}$ & $\mathrm{O}$ \\
\hline 0.007 & 0.04 & 0.74 & 0.022 & 0.013 & 1.05 & 0.31 & 0.157 \\
\hline \multicolumn{7}{c}{ Particle size distribution $(\mu \mathrm{m} / \mathrm{mass} \%)$} \\
\hline+250 & -250 & -180 & -150 & -106 & -75 & -63 & -45 \\
& +180 & +150 & +106 & +75 & +63 & +45 & \\
\hline 0 & 0.7 & 14.8 & 24.2 & 24.6 & 9.9 & 14.4 & 11.4 \\
\hline \hline
\end{tabular}

りうると考えられることから，0, $0.5,1$ および 2 mass\% の外， 4 mass\%としている.

計算によって低融点合金の候補組成を数種類求めた後，基 本成分である $\mathrm{Fe}$ を実験では $\mathrm{Cr}-\mathrm{Mo}-\mathrm{Mn}$ 鋼粉に置き換えて配合 し, 加圧力 $600 \mathrm{MPa} て ゙ 5 \mathrm{~mm} \times 5 \mathrm{~mm} \times 2 \mathrm{~mm}$ に成形した. 次に， 組成の異なるそれらの混合粉 (以後, 低融点粉と呼ぶ)の圧粉 体を一括して異なる温度に加熱し，溶融の痕跡の有無を確認 して低融点粉の最適組成を決定した。

2.3 試料の作製

Cr-Mo-Mn鋼粉に1 mass\%の黒鉛を添加した粉末を 100〜90 mass\%，上記で決定した最適低融点粉を0 10mass\%，この両者 を合わせて 100 mass\%とし，さらにステアリン酸冓鉛を 1 mass\% 添加してエタノールを加え，加熱しながら擋抖してエタノ一 ルを蒸発させた.この混合粉を $600 \mathrm{MPa}$ の両押しでMPIF 規格 10 の引張試験片金型により成形し，水素中 $870 \mathrm{~K} て ゙ 60 \mathrm{~min}$ 脱 ろう後, $1420 \mathrm{~K}$ のアルゴン雾囲気炉に入れて急熱し，60 min 保持して水冷ジャケット部で冷却 (約 $40 \mathrm{~K} / \mathrm{min}$ ) した.

2.4 試料の評価

寸法変化率は, 試料に加える測定圧力 $392 \mathrm{mN}(40 \mathrm{gf})$ の電子 式マイクロメータ(最小読み $0.001 \mathrm{~mm}$ )を用いて圧粉体および 燒結体の中央断面の加圧方向および横方向の寸法を測定し， 圧粉体を基準として各方向につき算出した。密度は，まず空 気中で試料を秤量後, シリコーン油(信越化学製 KF-96L)を真 空含浸し，次に水中で秤量してアルキメデス法で求めた。た だし，相対密度を求める際の鋼粉の真密度は便覧 ${ }^{11)}$ で見出し た類似鋼種の值を引用し，すべて $7.83 \mathrm{Mg} / \mathrm{m}^{3}$ とした。

組織は，加圧面に直角に切断研磨した面上で光学顕微鏡や EPMAによる観察を行うとともに微小硬さを測定し，別に引 張試験破面のSEM 観察も行っている.

\section{5 材料試験}

硬さ測定は引張試験片のつかみ部分で行い, ロックウエル Cスケールの值を求めた. 引張試験には電子制御式材料試験 機 (島津製作所製オートクララフ AG-G)を用い, クロスヘッド 速度 $1 \mathrm{~mm} / \mathrm{min}$ で引張強さを求めるとともに, 標点距離 $25 \mathrm{~mm}$ における破断伸びを測定した。

\section{3 結 果}

3.1 熱力学計算ソフトによる融点計算およひ低融点粉の組成決定 計算によって求めた融点(三元系の液相面と垂直断面の交線 温度) を Fig.1 に示す. 同図の 4 本の曲線は，4段階のC 添加 量について，B 添加量を変えた場合の融点を表す，各曲線に 現れる極小点は二元共晶線上の点に該当し,3本の二元共晶線 の交点に三元共晶点が存在する．極小点は，いずれも沉用焼 結炉の限界温度 $1423 \mathrm{~K}\left(1150^{\circ} \mathrm{C}\right)$ より低い融点になっているが， 最も低いのが2.5mass\%B-2mass\%Cの組成が示す計算值 $1394 \mathrm{~K}$ $\left(1121^{\circ} \mathrm{C}\right)$ であった. そこで同組成を基本として，微量の添加 量変化が融点に大きく影響しそうな $\mathrm{B}$ を $0.2 \mathrm{mass} \%$ 增減し, 計 3 種の組成を $\mathrm{Cr}-\mathrm{Mo}-\mathrm{Mn}$ 鋼粉に配合した小型の圧粉体を作り， ボートに並べて加熱溶融試験を行った。 


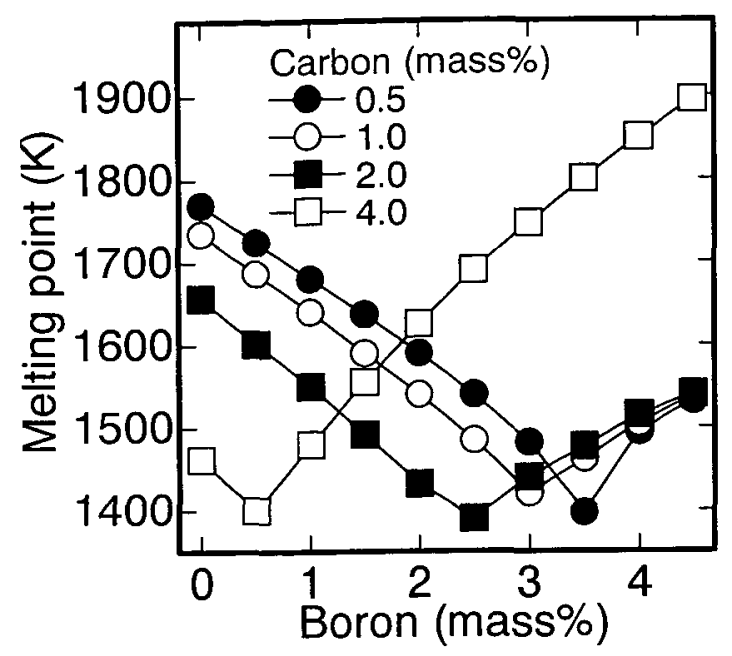

Fig.1 Melting points of $\mathrm{Fe}-\mathrm{B}-\mathrm{C}$ alloys calculated with ThermoCalc.

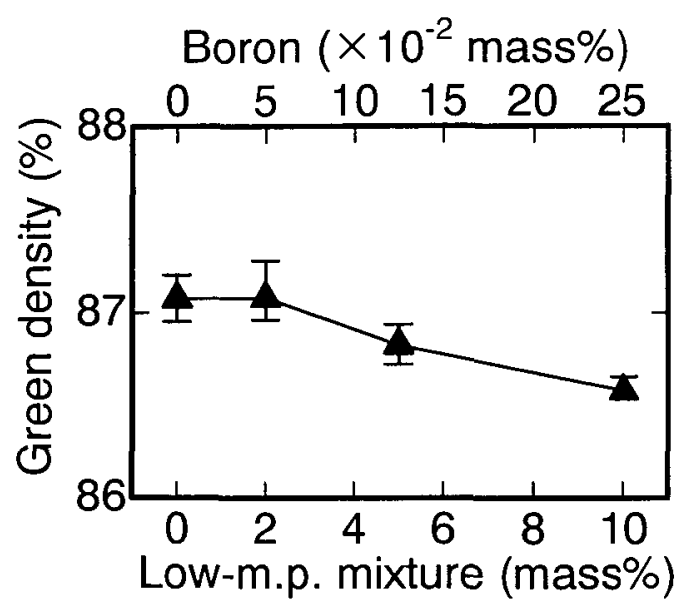

Fig.2 Effect of addition of low-melting-point mixture (Cr-Mo-Mn steel-2.5mass \%B-1mass $\% \mathrm{C}$ ) on green density of $1 \mathrm{mass} \% \mathrm{C}$ compacts.

その結果, 3種すべての組成の圧粉体が, 1400Kで板状の原形 が崩れる程度になったので, 㲸用炉の限界 $1423 \mathrm{~K}$ 以下で焼結 促進のための低融点粉として使用可能と判断される.この際， Bを 0.2 mass\% 増減することによって目立った違いは現れな かったので，以後に用いる低融点粉の組成は B 量を 2.5 mass\% とし，黒鉛の添加量を $1 \mathrm{mass} \% に$ 変更した．その理由は，母 粉末の黒鉛添加量に一致させておく方が, 低融点粉の添加量 の変化が全体のC濃度を変えて材質に影響することを回避で きるからである.この低融点粉を，あらかじめCr-Mo-Mn鋼粉 に1 mass\%の黒鉛を添加しておいた粉末に所定の割合で加え， 焼結特性に及ほす影響を調へることにした.なお， 1 mass\%の 黒鉛添加量から鋼粉粒子表面の脱酸に消費されるC量が差し 引かれるので ${ }^{12)}$ ，本実験における残留 C 量の実測值は例えば 0.74 mass\% が得られている.

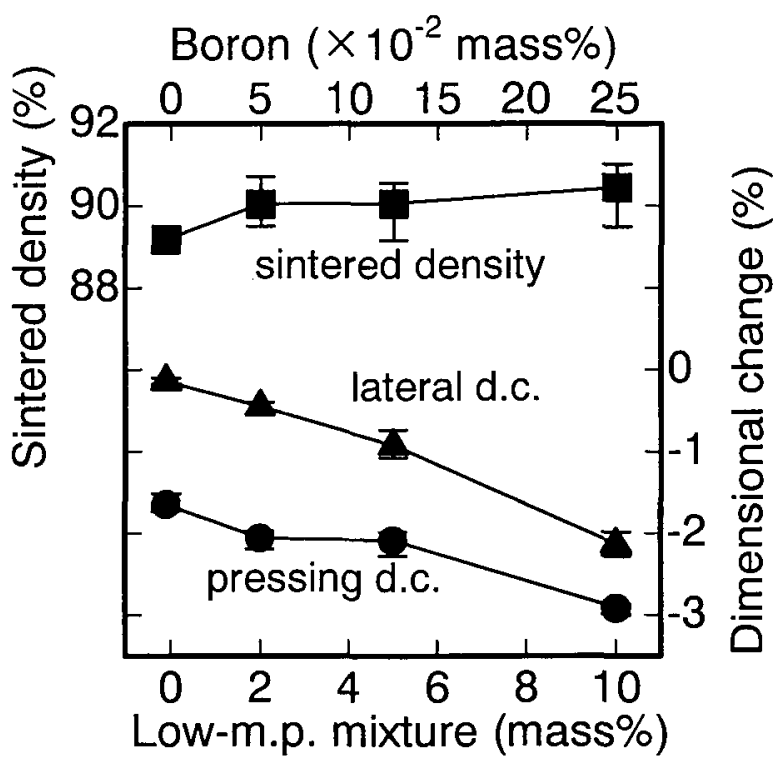

Fig.3 Effect of addition of low-melting-point mixture (Cr-Mo-Mn steel-2.5mass\%B-1 mass\%C) on densification of 1 mass \%C compacts during sintering at $1420 \mathrm{~K}$ for $60 \mathrm{~min}$ in $\mathrm{Ar}$ ).

\section{2 粉末の圧縮性と焼結緻密化挙動}

低融点粉の添加量が圧粉密度に及ほす影響を Fig.2に示す. 同図を含めて以後の図では低融点粉添加量を試料全体に含ま れるB量に換算した值も表示している.Fig.2によると添加量 2 mass\% (0.05mass\%B) 以上で量の增加に伴い密度が単調かつ 緩やかに減少している。

次に低融点粉の添加量が焼結緻密化挙動に及ぼす影響を Fig.3に示す. 添加量の増加に伴い，圧粉密度が減少したのと は逆に焼結密度が增加するが，2mass\% (0.05mass\%B) 以上の 添加では変化が小さい．収縮は添加量とともに大きくなる傾 向にあり，加圧方向の方が横方向より収縮が大きいという異 方性が現れているが，その異方性の程度つまり両方向の収縮 の差は，添加量が增して収縮が大きくなるとともに減少して くる.

3.3 組織

焼結緻密化の進展に対応して，Fig.4によれば，気孔の変化 が認められる. まず, 同図 (a)の低融点粉無添加のものに比べ て，それを1ないし 2 mass\%すなわち B 全体の 0.025 ないし 0.050 mass\%添加することによって同図(b)のように気孔はわず かに丸味を增す. 次に，その低融点粉 2 mass\% $(0.050$ mass\%B)の Fig.4(b)で見られる細長い気孔が，同図(c)の低融点粉 5 mass\% (0.125 mass\%B) では球に近い塊状の気孔に変わってくる. (d) の低融点粉 10 mass\% (0.25 mass\%B)では組織の粗大化, 気孔 の球状化という焼結進行に伴う特徵的変化が明膫に現れ，特 に 20 mass\% (0.50 mass\%B) では, 写真を省くが気孔の粗大化 が著しい。

基地組織は，低融点粉無添加の Fig.4(a)では，約 $1000 \mathrm{MHV}$ の硬さを持つ白い笹の葉状マルテンサイトに,ベイナイト(矢 

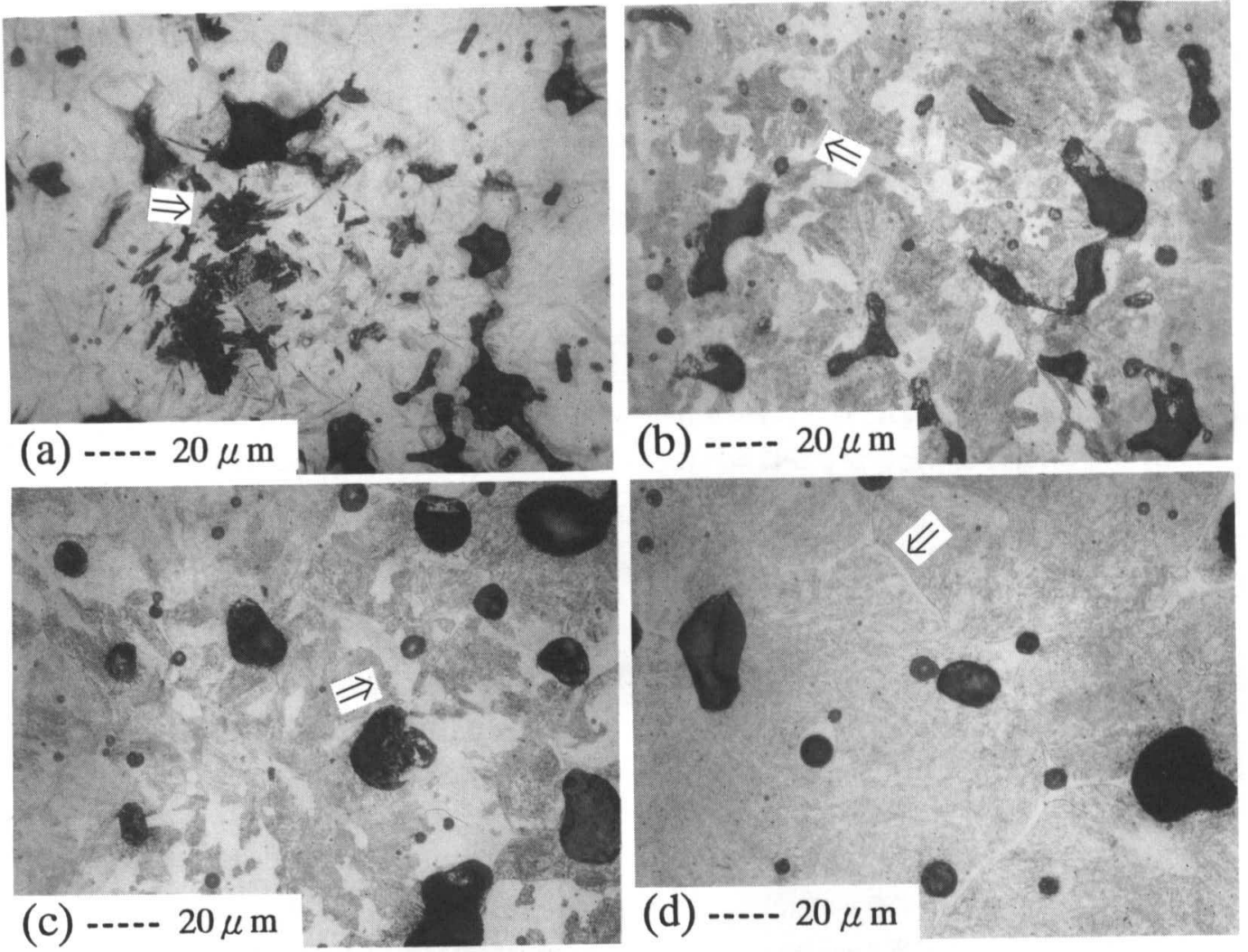

Fig.4 Optical microstructures of $1 \mathrm{mass} \% \mathrm{C}$ compacts containing different amount of low-melting-point mixture (Cr-Mo-Mn steel-2.5mass $\%$ B-1mass $\% \mathrm{C}$ ) and sintered at $1420 \mathrm{~K}$ for $60 \mathrm{~min}$ in $\mathrm{Ar}$. (a) without mixture (arrow: bainite), (b) 2 mass $\%$ of mixture ( $0.050 \mathrm{mass} \% \mathrm{~B})$ (arrow: bainite) (c) 5 mass \% of mixture $(0.125$ mass $\%$ B) (arrow: ferrite), (d) 10 mass $\%$ of mixture $(0.25$ mass $\%$ B) (arrow: ex-liquid).
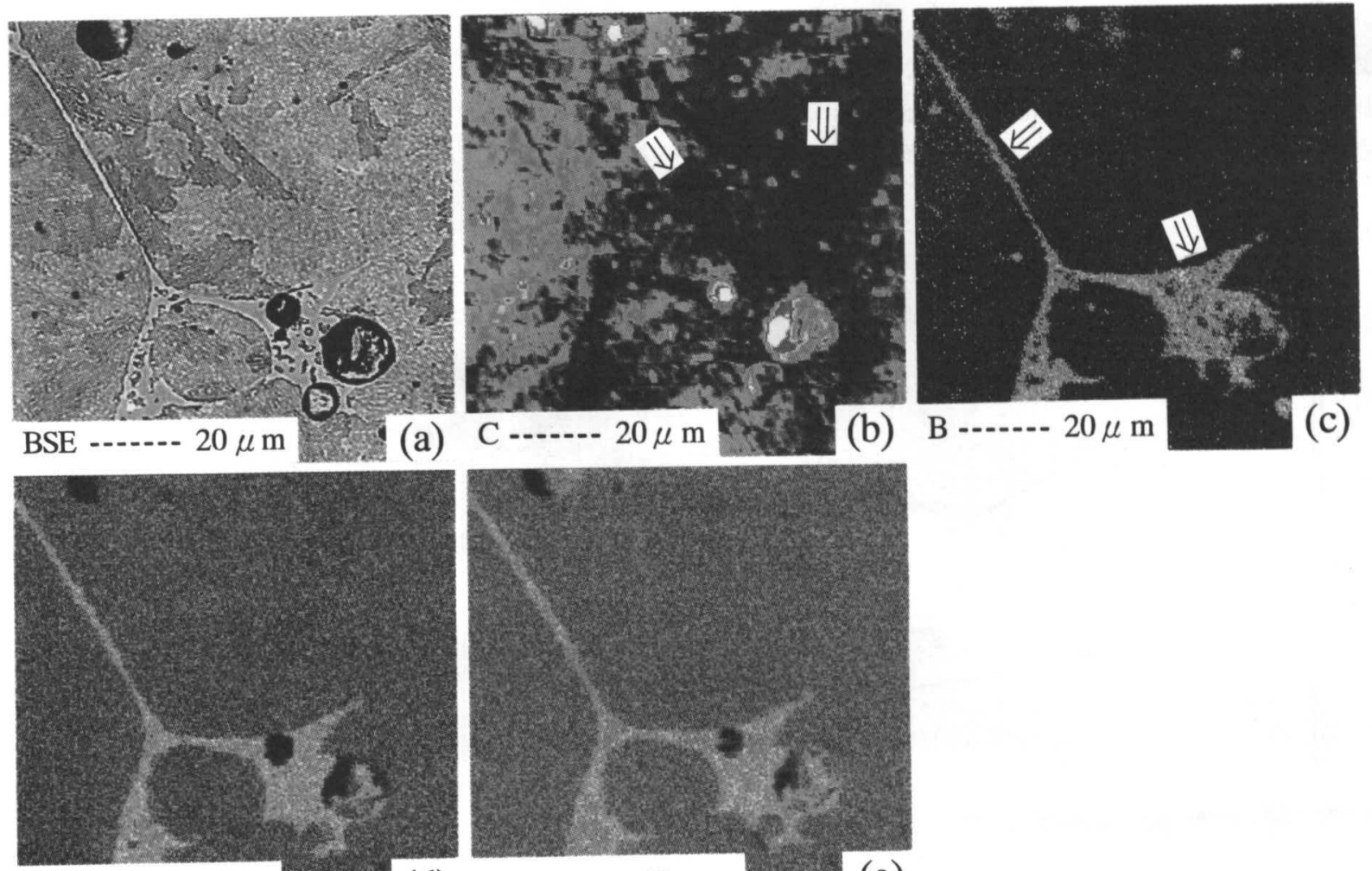

$\mathrm{Cr}-\ldots-.--20 \mu \mathrm{m}$

(d)

$20 \mu \mathrm{m}$

(e)

Fig.5 EPMA images of 1 mass \%C compacts containing 10 mass $\%$ of low-melting-point mixture (Cr-Mo-Mn steel-2.5mass\%B-1mass\%C) or $0.25 \mathrm{mass} \%$ of B and sintered at $1420 \mathrm{~K}$ for $60 \mathrm{~min}$ in Ar. (a) back-scattered-electron micrograph, (b) C image (arrow: ferrite), (c) B image (arrow: liquid), (d) $\mathrm{Cr}$ image, (e) Mo image. 
印)が塊状で分散したものになっている.これに低融点粉を添 加し，さらに量を増したとき，まず(b)のように塊状のベイナ イト (矢印) 加增加し, 次に 5 mass\% (0.125 mass\%B) 以上の添 加で (c)のようにマルテンサイトと異なる白色域 (矢印)がべ イナイトと共に現れる。この種の白色域は，例えばEPMAで 10 mass\% 添加 (0.25mass\%B) 材を面分析した Fig.5 (b) の矢印で 明らかなようにC睱度が低く，硬さ $300 \mathrm{MHV}$ 前後で，強いナ イタル腐食によってオレンジ肌の凹凸になる。

また，低融点粉が無添加または添加量が少ないときのFig.4(a) や(b)に示す組織に液相の跡が見られないのに対し, 添加量が 5 mass\% (0.125 mass\%B) の同図 (c)になると，かすかに粒界に 沿う細い白色相が現れ始め，その白色相は添加量 10 mass\% (0.25 mass\%B) 以上では同図 (d)やFig.5(c)の矢印のように液相 から凝固した形を持つ網目状や共晶組織になり，ナイタルで 腐食されない．この相は幅が狭く，硬さの測定が困難である が，1400MHVを越える測定值もあり，Fig.5(c)の矢印のよう にBが濃縮し，(d)の Cr および (e)の Mo 濃度も高い。

\section{4 引張特性および硬さ}

焼結密度の上昇, 収縮の増大, さらに組織の変化から, 低 融点粉の添加による焼結促進が確認できるので，次に機械的 性質の変化を調べた．Fig.6および7に結果を示す．

引張強さ (Fig.6)では, 低融点粉の添加量 2 mass\% (全体で $0.050 \mathrm{mass} \% \mathrm{~B}$ )のものが最も強く, 無添加と比べ $15 \%$ 程度改善 されている. しかし，それ以上添加すると逆に引張強さは低 下し，低融点粉 10 mass\% (0.25mass\%B)では無添加の值を下 回っている. 同じくFig.6に示す伸びはいずれの場合も $2 \%$ 以 下と極めて小さいため，はっきりした傾向は分からないか， 一応, 引張強さの曲線が低融点粉 $2 \mathrm{mass} \%$ ( 0.050 mass\%B)のと ころに極大を持って上に凸の形になっているのに似て，低融

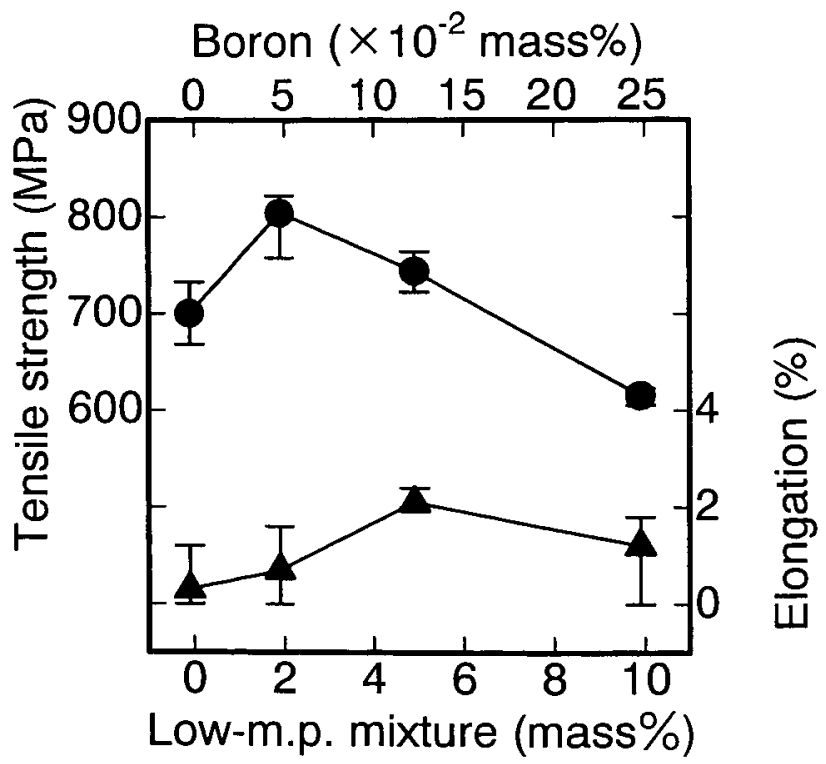

Fig.6 Effect of addition of low-melting-point mixture (Cr-Mo-Mn steel-2.5mass\%B-1mass\%C) on tensile properties of $1 \mathrm{mass} \% \mathrm{C}$ compacts sintered at $1420 \mathrm{~K}$ for $60 \mathrm{~min}$ in $\mathrm{Ar}$.
点粉 5 mass\% (0.125mass\%B)のところに極大を持っているよう に見受けられる。

硬さ(Fig.7)は低融点粉の添加量 5 mass\% (0.125mass\%B)まで の範囲ではHRC15程度であり，添加量の違いによってほとん ど変わらないか，低融点粉 $10 \mathrm{mass} \%(0.25 \mathrm{mass} \% \mathrm{~B})$ になると著 しく軟化して負の HRC測定值も現れるようになる.

以上の材貿変化の中で代表的な引張試験片の破面を, SEM 写真として Fig.8に示す. 低融点粉無添加の同図 (a) は破断前 に粒子間で接合していた面積が(b) および(c)に比べると小さ く，粒子の形がはっきり確認できる.最も強かった低融点粉 2mass\% (0.050mass\%B)の (b)では (a)より狫結が進行してお り，破面にはディンプルとへき界面の両方が湿在している. また気孔表面がなめらかであり，かつ，そこに現れたネック 部に粒界からにじみ出たような帯状のものがしばしば認めら れるので，燒結時に結晶粒界が液相で覆われていたことを示 すものかも知れない. (c)では同じ試料の組織観察(Fig.4(d))で かなりの粗大化が認められたのと同様に破面も粗くなってお り，大きなへき界面が目立つ。

\section{1 圧粉密度の変化}

$$
4 \text { 考察 }
$$

熱力学計算ソフト(Thermo-Calc)による計算および混合粉末 の溶融実験を経て決定した低融点粉組成 (Fe-2.5mass\%B$1 \mathrm{mass} \% \mathrm{C}$ ) は, 従来の文献に示されている Fe-B-C系三元共晶 点の平均的組成がほぼFe-3mass\%B-1mass\%Cであることに近 い。もちろん，本実験の結果には Cr や Mo が液相に濃縮する 効果も加わっており，鋼粉粒子表面の酸化膜による脱炭もあ るので,これをもって直ちに $\mathrm{Fe}-\mathrm{B}-\mathrm{C}$ 系の計算值や文献值が実 駼值と一致したと言うことはできないが，一応，混合粉末の 溶融によって見極める方法を, 熱力学計算ソフトによる計算 結果の簡便な検証法の一つと見なすことはできるであろう。

次に Fig.2の結果については, BやCが Feに比べて密度が

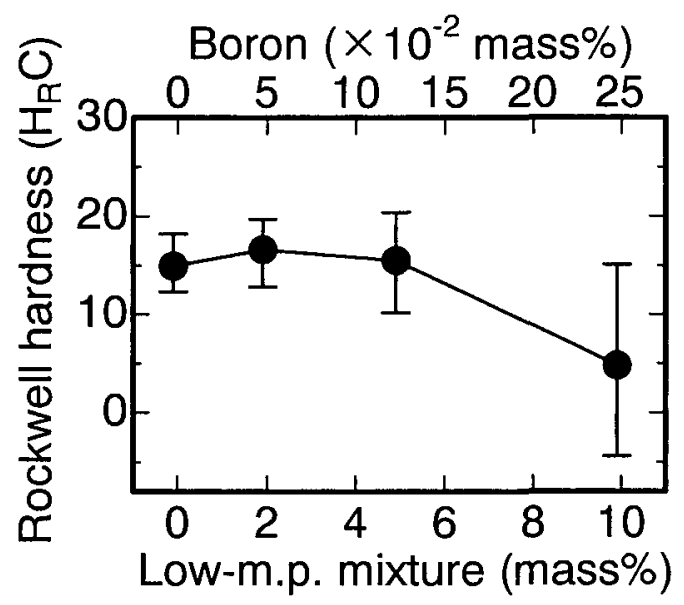

Fig.7 Effect of addition of low-melting-point mixture ( $\mathrm{Cr}-\mathrm{Mo}-\mathrm{Mn}$ steel-2.5mass\%B-1 mass \%C) on hardness of $1 \mathrm{mass} \% \mathrm{C}$ compacts sintered at $1420 \mathrm{~K}$ for $60 \mathrm{~min}$ in $\mathrm{Ar}$. 

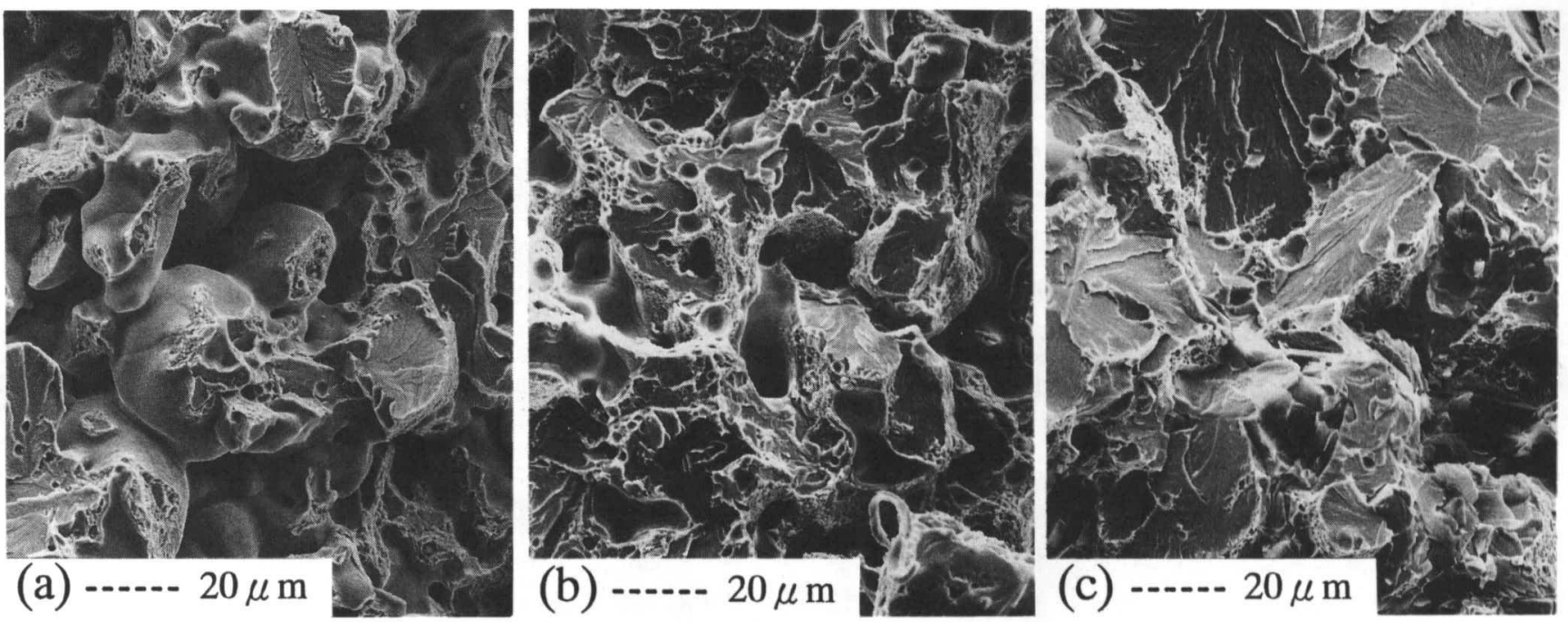

Fig.8 SEM fractographs of $1 \mathrm{mass} \% \mathrm{C}$ compacts containing different amount of low-melting-point mixture (Cr-Mo-Mn steel-2.5mass\% B$1 \mathrm{mass} \% \mathrm{C}$ ) and sintered at $1420 \mathrm{~K}$ for $60 \mathrm{~min}$ in Ar. (a) without mixture, (b) 2 mass $\%$ of mixture ( $0.050 \mathrm{mass} \% \mathrm{~B}$ ), (c) $10 \mathrm{mass} \%$ of mixture $(0.25$ mass $\% B)$.

低く,その低密度の粉末が少量でも体積の一部を占めるため, 低融点粉の添加によって圧粉密度が低下すると考える. 同図 において低融点粉の添加に伴って圧粉密度か緩やかに低下す るのは, まさにそのためであろう. Bを 2.5 mass\%配合した低 融点粉を 10 mass\% 添加すると, 全体に対して 0.25 mass\%B と なり，また Bの密度 $2.35 \mathrm{Mg} / \mathrm{m}^{3}$ と $\mathrm{Cr}-\mathrm{Mo}-\mathrm{Mn}$ 鋼の密度 $7.83 \mathrm{Mg} / \mathrm{m}^{3}$

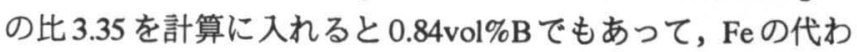
りにBが存在することによる体積增加は $0.84 \%-0.25 \%=0.59 \%$ と見積もられる. 従って, B の大半か鋼粉粒子の占めるべき 位置を代わりに占めて密度低下をもたらし，一部が元来気孔 となるべき粒子間隙に入って密度低下に寄与しなかったとす れば, Fig. 2 で低融点粉 10 mass\% 当たり約 $0.5 \%$ の密度低下が 起こることが十分に納得できる.

\section{2 焼結促進効果}

低融点粉の添加により Fig.3のように焼結密度が無添加と比 ベて増加するのは, 液相が生じて焼結が促進されるために違 いない，収縮に異方性があって加圧方向の方が横方向より大 きいのは, 成形・型抜き時のスプリングバックに伴い, 加圧 によっていったん接触した粒子の分離, あるいは加圧面と平 行な多数の微視的亀裂の発生が起こり, その段階の圧粉体で 焼結が行われると, 分離や龟裂か修復される際に相対的に大 きな収縮となって異方性が生じる ${ }^{13)}$ のであろう.

さらに, 密度の增大や強さの上昇, 伸びの改善に効果のあ る低融点粉の添加量 2 mass\%あるいは 5 mass\% が, 体積に換算 すると, 鉄系焼結機械部品に多く用いられているCuの添加体 積篹囲にほほ入っていることを指摘しておきたい.このこと について厳密に考察するには生じた液相の体積を知る必要か あるが, その体積の見積は, 実際の液相の組成と密度が不明 のために概略にならざるを得ない。しかし，Fe 基合金である この $\mathrm{Fe}(\mathrm{Cr}, \mathrm{Mo})-\mathrm{B}-\mathrm{C}$ 系液相と鉄飽和 $\mathrm{Cu}$ 融液とを極めて大ま
かにほぼ同密度と見なせば，現用の機械部品材料の中心的組 成である $\mathrm{Fe}-(1-5)$ mass\% $\%$ u-1mass\%Cの場合と同程度の体積の 液相が生じて, 同程度の焼結促進効果を発揮したと考えるこ とができる.すなわち，重合金 ${ }^{14)} に$ 比べて利用する液相量の 少ない鉄系機械部品でも，液相焼結をもたらす添加物の効果 は, その液相が占める体積によるところが大きいのではない かと推測される.

低融点粉の添加による焼結促進は Fig.4 の組織や Fig.8 の破 面からも分かり, 添加量増大に伴ってネックの成長と気孔の 鋭角部消失, 個々の気孔の成長と総気孔体積の減少等の効果 が生じている．添加量が少ないときには液相は等温凝固によ り消滅し, 焼結組織に液相の跡が見られないのに対し, 添加 量が多いと液相は加熱中を通して存在し, 焼結後も溶製材の 凝固組織 ${ }^{15}$ と同様に粒界に沿う硬く脆いほう炭化物系の相や 共晶組織の網目を残すようである. そのため, 添加量が少な ければ焼結促進による強勒化のみが起こり, 多ければ脆い網目 による脆弱化が起こるのであろう. 低融点粉の添加量 10mass\% (0.25mass\%B)の場合に, 5 mass\% $(0.125$ mass\%B)に比べて引張 強さ，伸ひ，硬さがすべて低下した原因は，まさに，この網 目のためと思われる.ここで液相が B と共に Cr や Mo を多く 含むことは, $1470 \mathrm{~K}$ 程度の温度で焼結したステンレス鋼 ${ }^{10 て ゙ ~}$ 観察されているところと一致するが, 本実験では約 $50 \mathrm{~K}$ 低い 焼結温度でそのような液相が出現している。この低い液相発 生温度は, 井手等 ${ }^{17}$ が $\mathrm{Fe}-\mathrm{Mo}-\mathrm{Cr}$-B 系硬質合金の焼結で急激 な収縮を見出している温度に近く,さらに本実験の焼結体は 0.7-0.8 mass\%の残留C濃度を有しているので, それも融点降 下に寄与しているであろう。

\section{3 金属組織の変化}

金属組織は, Fig.4(a)の低融点粉無添加の試料で，約 1000 MHVという微小硬さの值からマルテンサイトと判断される笹 
の葉状の中に，少量のベイナイトが分散している．このべイ ナイトが, 低融点粉が 2 mass\% (0.050mass\%B)までの少ない範 囲で同図(b)のように添加量とともに増加するのは, 上野 ${ }^{18)}$ が 見出している多量の B による焼入性低下現象と考えられる。 彼は，溶製の 0.0005 mass\%B鋼に比べて 0.0020 mass\%B 鋼の方 が変態析出時間が短縮され，ベイナイトが現れやすくなると 述へている. また，Fig.4(c)，(d)のように低融点粉の添加量か 5 mass\% (0.125mass\%B)以上のところで現れる白色組織は, 強 い腐食によるオレンジ肌の凹凸形成, 300 MHV前後の硬さ值, および低いC濃度から，やや硬いがフェライトと判断される。

このように共析組成に近いC濃度の鋼において，Bの共存 でフェライトが出現しやすくなることに関連して，金子等の 報告 ${ }^{15)}$ がある. 彼等によると，B の存在でオーステナイト中 に固溶できるCの濃度が著しく低下するという，従って， Fig.5(b)に見られる極めて高濃度のCは, 未固溶の残留黒鉛で ある可能性が大きい。また Fig.6の強さがBの少ない範囲での み改善されることは，Cの固溶が妨げられないためとして明 快に説明できる。

なお，上ノ薗等 ${ }^{19}$ が $\mathrm{B}$ を含む $0.7 \mathrm{mass} \% \mathrm{C}$ 鋼について，冷却 時にオーステナイトが気孔中に黒鉛を晶出してフェライトに なると報告していることについては，別の事情を考虑する必 要がある. 彼等はその鋼を $\mathrm{N}_{2}-\mathrm{H}_{2}$ 混合雾囲気で焼結している ので，早い焼結段階から B が窒化ほう素となって析出してい る可能性がある.その結果, オーステナイトへのCの固溶か 妨げられなくなるとすれば，一旦は固溶Cが增大し，それが 冷却時に窒化ほう素の上に同じ結晶形を持つ黒鉛としてエピ タキシャルに析出するのであるう ${ }^{20)}$.

\section{5 結言}

鉄鋼材料のリサイクルを促進するには，自動車に多く用い られている鉄系焼結機械部品から，焼結促進などのために加 えられているCuを除く必要がある.そこで熱力学計算ソフト (Thermo-Calc)による計算の結果，Fe-2.5mass\%B-1mass\%Cの 合金組成が $\mathrm{Cu}$ に準じる低融点 $1394 \mathrm{~K}\left(1121^{\circ} \mathrm{C}\right)$ であることを 見出した. その計算組成中の Fe を Cr-Mo-Mn 鋼粉に代えて調 製した低融点混合粉を，さらに Cr-Mo-Mn 鋼粉に $1 \mathrm{mass} \%$ の 黒鉛を添加した粉末と混合し，それを成形後，Cuを含む鉄系 材料の焼結に一般的に用いられる炉の上限温度にほぼ相当 する1420Kで燒結した。

低融点粉を添加すると，焼結が促進されてほとんどの場合 に密度は增加する. 1 mass\% の黒鉛を含む Cr-Mo-Mn 鋼粉に 添加して最も大きな材質改善が達成されるのは, Cr-Mo-Mn 鋼粉-2.5mass\%B-1mass\%C の低融点粉を 2 mass\% 添加する場 合であって，全体組成は 0.05 mass\%B-1mass\%Cとなり，B 無 添加の Cr-Mo-Mn 鋼粉-1mass\%Cの場合と比へて引張強さが $15 \%$ 程度增加する。

\section{謝辞}

本研究を発表するに当たり，広島大学工学部の卒業研究と
して実験に協力された増田秀基，山村大輔，森本浩の各氏に 感謝し，鉄瞩スクラップの現状についてお知らせ下さった国 内鉄鋼業各社の方々，並びに鋼粉と黒鉛粉を提供して下さっ た川崎製鉄(株)と日本黒鉛工業侏の両社に厚く御礼申し上げま す. また本研究の経費は文部省科学研究費補助金によってま かなわれたことを付記します.

\section{文献}

1) H.Katayama and Y.Minakami: Materia Japan, 35(1996)12831289.

2) T.B.Massalski et al.: Binary Alloy Phase Diagrams, Vol.1, ASM, (1986)482, 562.

3) P.Nash, C-J.Wen, M.Phillips and E.Lumpkins: "The Influence of Boron and Sintering Atmosphere on the Sintering and the Mechanical Properties of FC0208", Advances in Powder Metallurgy and Particulate Materials, Vol.1, 1(1995)4.77-4.93.

4) V.F.Tkachenko and Y.I.Kogan: "Structural Characteristics and Mechanical Properties of Sintered Fe-B4C Materials", Soviet Powder Metallurgy and Metal Ceramics, 17(1978)384-388.

5) J.P.Poirier and M.Gagne: "A New Approach to Improve Machinability of High Strength P/M Parts", Advances in PM Parts Production, Amsterdam, MPR Publishing Services Ltd., (1990)4.1-4.12.

6) G.Han, M.Tada, H.Kuroki and K.Shinozaki: "Mechanism of Enhanced Sintering of Stainless Steel by Fluxing", J. of the Japan Soc. of Powder and Powder Metallurgy, 43(1996)241-248.

7) M.L.Borlera and G.Pradelli: "The Fe-B-C System", Metallurgia Italiana, 60(1968)140-146.

8) E.Schurmann and S.X.Li: "Investigation of the melting equilibrium of the ternary system iron-carbon-boron", Giessereiforschung, 37(1985)121-129.

9) T.Yamashita, A.Matsuzaki, S.Takajo and M.Hasebe: "Precipitation Behavior of Cementite in Fe-0.8mass\%C- 0.1 mass\%B Alloy", J. of Japan Institute of Metals, 63(1999)708-716.

10) M.Hasebe: Research Review on Boron in Steels and Targets for Next Century, Japan Iron and Steel Institute, (1999)1-21.

11) C.J.Smithells: Metals Reference Book, 5th Edition, Butterworths, (1976) 961.

12) J.S.Hirschhorn: Powder Metallugy, American Powder Metallurgy Institute, (1969)225.

13) H.Kuroki: "Anisotropy in the Dimensional Change of Metal Powder Compacts during Sintering", Sintering'87, Vol.1, S.Somiya et al. ed., Elsevier Applied Science, (1988)387-392.

14) R.M.German: Liquid Phase Sintering, Plenum Press, (1985)223229.

15) H.Kaneko, T.Nishizawa and A.Chiba: "Borides and Carbides in the System of Fe-B-C", J. of Japan Institute of Metals, 30 (1966)263-269.

16) A.Molinari, J.Kazior, F.Marchetti, R.Canteri, I.Cristofolini and 
A.Tiziani: "Sintering Mechanisms of Boron Alloyed AISI 316L Stainless Steel", Powder Metallurgy, 37(1994)115-122.

17) T.Ide and K.Nakano: "Effects of $\mathrm{Cr}$ and Mo Contents on Sintering Mechanisms of Mo2FeB2 Base Hard Alloys", J. of the Japan Soc. of Powder and Powder Metallurgy, 36(1989)3842.

18) M.Ueno: "Study on the Hardenability of Boron Steels", Thesis, Kyushu University, (1988)24.
19) S.Uenosono, K.Ogura, Y.Nakano and J-B.Yang: "Formation of Free Graphites during Sintering Green Compact Made of Mixture of Iron Powder Including Boron and Graphite", J. of the Japan Soc. of Powder and Powder Metallurgy, 44(1997)870875.

20) T.Iwamoto, H.Ota, T.Hoshino, K.Amano and J.Shimomura: Graphite Nucleation on Boron Nitride in $0.53 \%$ C Steel", Tetsuto-Hagane, 84(1998)67-72. 